\title{
COMPARATIVE EFFECTS OF CORTISONE, ACTH, AND DOCA IN A CASE OF RHEUMATOID ARTHRITIS WITH ADDISON'S DISEASE*
}

\author{
BY \\ PHILIP ELLMAN and LEON CUDKOWICZ \\ From the Rheumatism Unit, St. Stephen's Hospital, London
}

(RECEIVED FOR PUBLICATION APRIL 25, 1952)

The association of " rheumatoid disease" (Ellman and Ball, 1948) and Addison's disease is exceedingly rare. Kendall (1951) believed that their co-existence was no more than a coincidence. Perera and Ragan (1950) and, more recently, Caughey and McCoy (1951) reported single cases of a combination of the two diseases. The last mentioned refer to the French literature (Dejean, 1947; de Gennes and others, 1947; Laroche, 1947), where rheumatoid joint lesions were also described in conjunction with Addison's disease.

\section{Case Report}

The present case is that of a housewife, aged 53, who was first seen at the Rheumatism Unit in September, 1951. She complained of

(a) swelling of both wrists and pain in the second toe of the left foot;

(b) physical exhaustion;

(c) change in skin colour.

History.-Her joint symptoms dated from the early part of 1947. They had begun with severe stabbing pain in both arms and shoulders, followed by swelling of the fingers necessitating the cutting of her rings. Subsequently her knees became tender and swollen, and she was instructed to stay in bed for 6 weeks. After this period of rest in bed she received a course of gold injections with considerable benefit to all the affected joints.

In 1949 the polyarthritis recurred, and responded to a second course of gold. Later in the same year, she became aware of extreme fatigue after her normal activities and frequently fainted. In May, 1950, she developed a right-sided pneumonia and was ill for some weeks. After gradual improvement the joints flared up once more and lassitude became extreme. In the later part of that year she had to reduce her normal

- This paper is based upon a contribution to the discussion following a Symposium on the Suprarenal Cortex held by the Colston Research Society at the University of Bristol in April, 1952. This Symposium was reported in the June issue of this Journal (Annals of the Rheumatic Diseases, 1952, 11, 173). household duties to a bare minimum. The attacks of fainting became much more numerous, and she often vomited without warning or nausea. This vomiting was not related to meals.

Six months before admission, she was told that her face and neck were changing colour, and she herself observed the development of brown patches on her hands, arms, shoulders, and upper abdomen. The intensity of the pigmentation appeared to vary from day to day. She was anorexic, the attacks of vomiting increased to four per week, and she lost about $1 \frac{1}{2}$ stone in weight. Stooping caused vertigo, dyspnoea, and sometimes loss of consciousness. There was no history of polyuria or polydipsia.

She had had an appendicectomy in 1926 and a hysterectomy for fibroids in 1939.

A son had died at the age of 16 after pneumonia complicated by meningitis.

Examination.-The patient was admitted under the care of one of us (P.E.) on 8.9.51. She was a thin, alert woman weighing 6 stone. The skin of her neck and face was mildly bronzed. Bronze patches covered the dorsum of both hands and wrists, and also the epigastrium. The palmar skin creases were dark.

Clinical Findings.-Conjunctivae and fundi normal.

She was edentulous, tongue moist, no pigmentation of oral mucous membranes.

Trachea central, no jugular vein pulsation, no cervical adenopathy. Right epitrochlear gland palpable and tender.

Cardiovascular system: apex beat in 5th intercostal space 4 in. from mid-sternal line. Apical sounds normal. P2 accentuated and split. Blood pressure $95 / 60$. Pulse rate and rhythm normal. Ankles and sacrum free of oedema. Peripheral pulses equal and normal.

Lungs: antero-posterior chest diameter increased; movements, percussion note, and air entry at right base diminished; multiple expiratory rhonchi audible in same area.

Abdomen: left kidney palpable.

Central nervous system: no abnormality.

Axillary and pubic hair normal.

Locomotor system: both wrists swollen and tender: extension and flexion diminished; metacarpophalangeal 
and proximal interphalangeal joints normal. Right grip $=30 \mathrm{~mm}$. $\mathrm{Hg}$, left $35 \mathrm{~mm}$. Tenderness, but no swelling, over metatarsals of left foot. Other joints and spinal rotation and flexion normal.

Radiological Findings.-Chest revealed increased vascular markings at bases and thickening of right basal pleura. Some puckering of dome of right diaphragm, but movements normal.

Heart shadow normal in size and contour.

Hands showed evidence of old rheumatoid arthritis of the wrists with erosive areas in carpal bones and moderate osteoporosis.

Abdomen showed suggestive evidence of calcification in right adrenal region.

Intravenous pyelogram normal.

Special Investigations.-Electrocardiogram normal. Blood sedimentation rate 18 in 1 st hour (Westergren).

Wassermann reaction and gonococcal complementfixation test negative.

Mantoux test $1 / 10,000$ negative, $1 / 1,000$ positive.

Sputum repeatedly negative for tubercle bacilli.

Laryngeal swab and faeces negative.

Lowenstein and guinea-pig culture negative.

Fractional test meal revealed hypochlorhydria.

\section{Blood Count.-}

Haemoglobin $=13 \cdot 7 \mathrm{~g} .=$ 92 per cent.

Red blood cells $=4 \cdot 7$ mils.

White blood cells $=6,300$

Differential count normal.

Blood urea $=29$.

Serum uric acid $=3 \cdot 2$.

Plasma proteins normal.

Liver function test normal.

\section{Urine.-}

No casts or organisms

Few leucocytes

Average specific gravity in morning specimen, 1,017

Average chlorides in morning specimen $10 \mathrm{~g}$. (Fantus)

17-ketosteroids $24 \mathrm{hrs} 2 \cdot 1$ mg.

Fasting blood sugar $61 \mathrm{mg}$. per cent.

Glucose tolerance curve; rise to $139 \mathrm{mg}$. in 60 min., fall to $58 \mathrm{mg}$. per cent. in $120 \mathrm{~min}$.

Serum electrolytes:

$\mathrm{Na} \quad 320 \mathrm{mg}$. per cent. K $\quad 18 \cdot 2$ mg. per cent. Chlorides $502 \mathrm{mg}$. per

Thorn's test $(20$ cent. ACTH), fall of eosinophils from 1,300 to 250 in $4 \mathrm{hrs}$.

Water Diuresis Test (Kepler-Power-Robertson, see Levy and others, 1946).-

Water load $1,000 \mathrm{ml}$.

Nocturnal specimen $780 \mathrm{ml}$-CChlorides 14

Hourly specimens $\left\{\begin{array}{lr}1 . & 60 \mathrm{ml} . \\ 2 . & 245 \mathrm{ml} . \\ 3 . & 30 \mathrm{ml} . \\ 4 . & 30 \mathrm{ml} .\end{array}\right\}$-Chlorides 8

Total $=365 \mathrm{ml}$.

Treatment.-The clinical history was suggestive of adrenal insufficiency and rheumatoid arthritis, and it was decided to ascertain the effects of

(a) ACTH, (b) Cortisone, (c) DOCA, separately and consecutively in relation to the follow ing features:

(1) Eosinophils

(2) Right hand grip

(3) B.S.R.

(4) Weight

(5) Water diuresis

(6) Blood pressure

(7) Serum electrolytes

(8) Urinary chlorides

(9) 17-ketosteroids

(11) Wrist pain and swelling.

\section{Results}

The results are summarized diagrammatically in Figs 1 and 2.

ACTH (Fig. 1).-With a daily dose of $45 \mathrm{mg} \overrightarrow{\vec{\omega}}$ ACTH the wrist swelling and tenderness, as well as the palpability and tenderness of the epitrochlean glands, disappeared. The eosinophils remained depressed throughout, the weight and B.S.R $\omega$ remained unchanged. The right grip improved a the wrist pain and swelling subsided. Although feeling of well-being was experienced the fatigue persisted. The skin colour did not alter. The diastolic blood pressure rose from 60 to $80 \mathrm{~mm}$. Hg The serum chlorides increased to 550. There wa no significant change in water diuresis, but the urinary chlorides fell below 10 . There was nळ change in the 17-ketosteroid excretion.

Cortisone (Fig. 1).-The initial cortisone dosagesol $25 \mathrm{mg}$. for 3 days and $50 \mathrm{mg}$. for 10 days was finallo maintained at $75 \mathrm{mg}$. daily for 10 days. With this dosage the joint symptoms and swelling completelp subsided, and the right grip rose to $70 \mathrm{~mm}$. Hgu Euphoria was experienced throughout the 10 day 8 of the $75-\mathrm{mg}$. course of cortisone, and the righ epitrochlear gland remained impalpable. The average diastolic pressure was $80 \mathrm{~mm}$. $\mathrm{Hg}$. The B.S.R. fell to $10 \mathrm{~mm}$. The skin became muct lighter towards the end of the course. There was no increase in weight, and the eosinophils after the end of the $75-\mathrm{mg}$. period rose to 200 . The seruno sodium climbed to $346 \mathrm{mg}$. and the serum chloride to $562 \mathrm{mg}$. The urinary chlorides remained below 10. A maximum total diuresis of $1,080 \mathrm{ml}$. was obtained at the height of the $75 \mathrm{mg}$. course with \& maximum single specimen of $480 \mathrm{ml}$. in the $2 \mathrm{nd}$ hour. Subjectively the patient felt stronger thas at any time in the preceding 10 months. With the reduction of cortisone to $25 \mathrm{mg}$. daily, wrist stiffnes? and pain recurred. On withdrawal of cortisone the patient became depressed and anxious. The epit trochlear glands became palpable again on the 4th day after the end of the course. Although the skip remained paler, the feeling of lassitude and fatigue reappeared within 2 days of the withdrawal of cortisone, although the patient was not told that cortisone had been discontinued. 


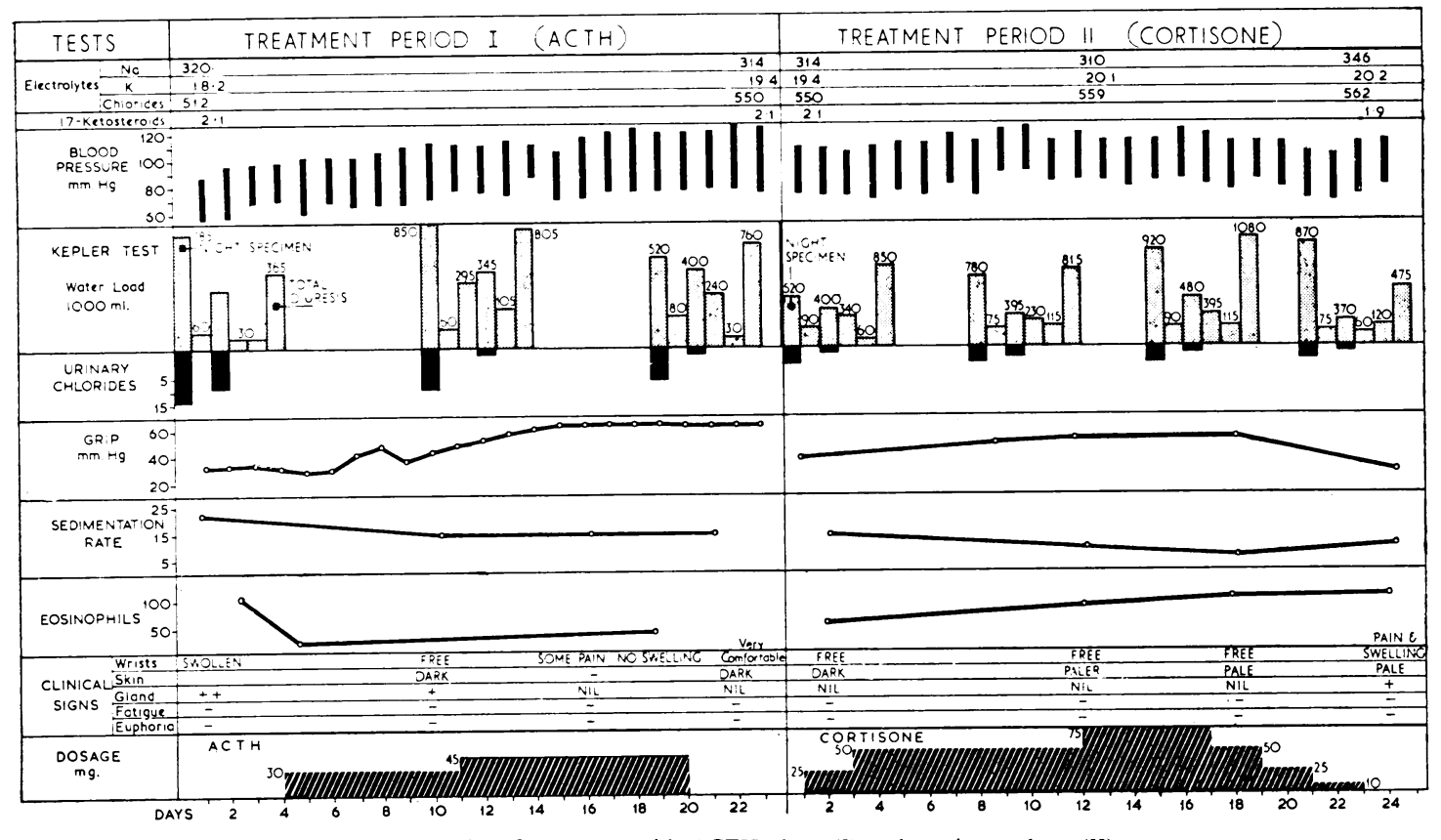

FIG. 1.-Results of treatment with ACTH alone (I) and cortisone alone (II).

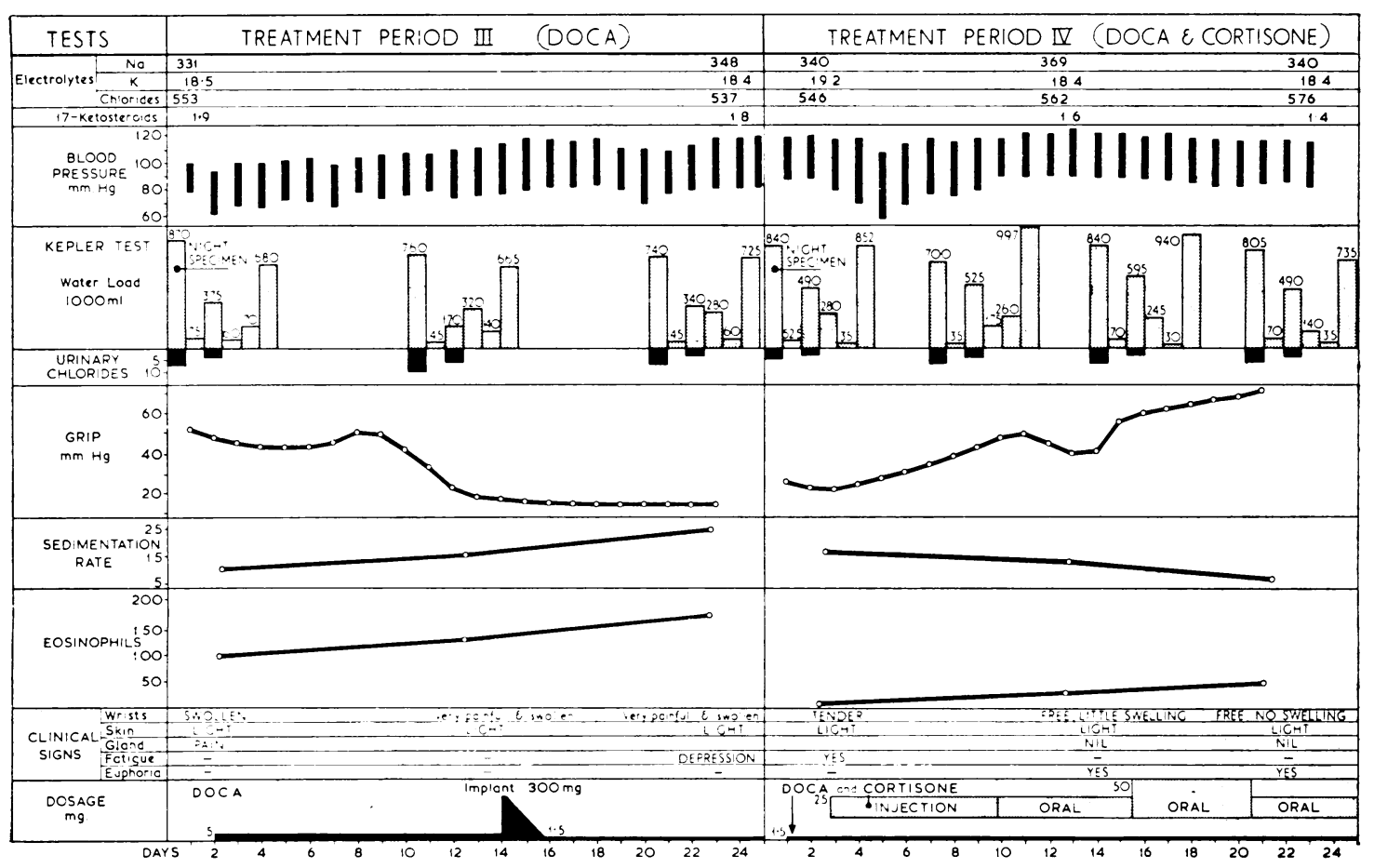

FIG. 2.-Results of treatment with DOCA alone (III) and DOCA combined with cortisone (IV). 
Owing to the difficulty in maintaining the patient indefinitely on cortisone, the opinion of Dr. P. M. F. Bishop was sought. He agreed that the evidence favoured the diagnosis of adrenal insufficiency, and recommended that the effects of $5 \mathrm{mg}$. DOCA and $6 \mathrm{~g}$. added salt daily should be examined. If the response to DOCA proved favourable, as far as the Addisonian symptoms were concerned, an implant of $300 \mathrm{mg}$. DOCA furnishing $1.5 \mathrm{mg}$. per day, should be instituted. This implant was introduced on the 13th day after the daily use of $5 \mathrm{mg}$. of DOCA.

DOCA (Fig. 2).--Rapid exacerbation of wrist swelling and tenderness and painful enlargement of the epitrochlear glands took place in the early part of the course. The right grip fell to $28 \mathrm{~mm}$. $\mathrm{Hg}$. The patient felt depressed, but less fatigued. The eosinophils rose by 100 per cent. The B.S.R. on the 13th day of DOCA was raised to 20. Weight reduction was minimal. The diastolic blood pressure at first fell to 60 , but rose steadily and stayed at 80 towards the end of the course. The urinary chlorides remained below 10 . Total diuresis at no time exceeded the nocturnal specimen, and the largest hourly specimen was always less than 50 per cent. of the night specimen.

After the DOCA implant the patient was discharged for 2 weeks, and she was readmitted as soon as further cortisone supplies became available. The response to DOCA, as far as the joints are concerned, was very disappointing, but it was thought that a smaller dose of cortisone would now be needed to maintain her joints in comfort, and to restore the water diuresis to its previous level. On readmission the wrists were puffy, the epitrochlear glands large and painful and the right grip $30 \mathrm{~mm}$. $\mathrm{Hg}$. The patient was depressed and fatigued. The skin colour was good.

Combined Effects of Cortisone and DOCA Implant (Fig. 2). - $25 \mathrm{mg}$. cortisone were used by injection for 11 days, followed by oral doses not exceeding $50 \mathrm{mg}$. daily. Improvement in the wrist joints occurred on the 8th day of this regime and was associated with a feeling of well-being. The right grip rose after initial fluctuations to $60 \mathrm{~mm}$. Hg. A gradual rise of the diastolic pressure to an average of $90 \mathrm{~mm}$. $\mathrm{Hg}$ became apparent in the second week. This was associated with some sodium and chloride retention, and a further fall in urinary chlorides. The water diuresis became modified and nearly normal towards the end of the 50-mg. period. The B.S.R. fell from 20 to 3 . The eosinophils gradually climbed from 10 to 56 . The weight remained constant, and there was no change in the daily excretion of 17-ketosteroids. The haemoglobin level, initially $12 \cdot 5 \mathrm{~g}$., reached $14.9 \mathrm{~g}$. at the end of the course.

The patient was discharged on a maintenance dose of $25 \mathrm{mg}$. cortisone daily by mouth.

\section{Discussion}

Kendall (1951), amongst others, contends tha $\vec{P}$ there is no real evidence that rheumatoid disease constitutes an endocrine disorder. The present case suggests that the adrenal insufficiency occurrey incidentally after the joint manifestations had become established. The response of the joints $t \vec{\sigma}$ ACTH was independent of any true effects on wate diuresis or 17-ketosteroid excretion. Cortisone appeared to be of definite value in alleviatings symptoms in both conditions, although reversal of water diuresis to normal was not accomplishedes DOCA had no effect on the joint manifestationso These findings accord with the view of Perera and Ragan (1950), who observed that $25 \mathrm{mg}$. cortisone daily would improve joint manifestations as well as Addisonian symptoms. The additional use 8 ह50 DOCA led to hypertension. This could be reversed after its withdrawal. The use of higher doses cortisone, i.e. $100 \mathrm{mg}$. daily, had no advantage orep smaller dosages. Thorn and Bayles (1949) founde that Addison's disease could be controlled by 10 ton $20 \mathrm{mg}$. cortisone daily alone. Salassa (1950) usedo $3 \mathrm{mg}$. DOCA daily, and $25 \mathrm{mg}$. cortisone twice weekly in one case of Addison's disease, and $3 \mathrm{mg}$ 을 DOCA and $15 \mathrm{mg}$. cortisone daily in another with excellent effect, whereas in a third case, $50 \mathrm{mg}$ cortisone daily did not prevent the loss of sodium and chlorides. It would appear, therefore, tha cortisone alone controls electrolyte balance as adequately as DOCA. The quantity of cortisone needed for the arrest of Addisonian symptoms appears to be less than the suppressive dosages needed in rheumatoid disease (Thorn and others, 1951). The suppressive dosage for the joint symptoms in the present case was certainly less thane is usual in similar cases of uncomplicated rheumatoio. arthritis. Chalmers and Lewis (1951), Oleesky ando Stanbury (1951), Slessor (1951), and Lloyd and Lobotsky (1950) have made some observations regarding the electrolyte control of cortisone. The last named suggested that patients with adrenaf insufficiency show defective diuresis because of a raised serum antidiuretic hormone level. In? Slessor's view, circulating posterior pituitary hor mone becomes inactivated by cortisone, thuso 
restoring the time and quantity of diuresis in Addison's disease. Garrod and Burston (1951), however, observed only partial restoration.

In the present case, only partial reversal of diuresis was observed with the dosages of cortisone employed. Sodium and chloride retention occurred with as small a dose as $25 \mathrm{mg}$. cortisone and $1.5 \mathrm{mg}$. DOCA. Sprague and others (1950) and McIntosh and Holmes (1951) believe that cortisone supresses adrenal function as evidenced by the delay of normal 17-ketosteroid excretion after cortisone. Some lowering of the 17-ketosteroid excretion occurred in this case during the prolonged course of cortisone.

\section{Summary}

The effects of ACTH, cortisone, DOCA, and cortisone and DOCA combined were studied in a case of rheumatoid arthritis, complicated by adrenal insufficiency. It was found that cortisone alone controlled both the joint lesions and the adrenal insufficiency. A true reversal of water diuresis did not, however, take place after cortisone. The action of cortisone in relation to adrenal insufficiency is discussed.

We are greatly indebted to Dr. P. M. F. Bishop for his help and advice in this case.

\section{REFERENCES}

Caughey, J. E., and McCoy, J. E. (1951). Brit. med. J., 2, 1189. Chalmers, T. M., and Lewis, A. A. G. (1951). Lancet, 2, 1158. Dejean, C. (1947). Presse méd., 55, 439.

Ellman, P., and Ball, R. E. (1948). Brit. med. J., 2, 816.

Garrod, O., and Burston, R. A. (1951). Communication to Medical Research Society (May).

de Gennes, L., Mahoudeau, D., and Bricaire, H. (1947). Bull. Soc. méd. Hôp. Paris, 63, 532.

Kendall, E. C. (1951). Brit. med. J., 2, 1295.
Laroche, G. (1947). Bull. Soc. méd. Hôp. Paris, 63, 616.

Levy, M. S., Power, M. H., and Kepler, E. J. (1946). J. Clin. Endocrinol., 6, 607.

Lloyd, C. W., and Lobotsky, J. (1950). J. clin. Endocr., 10, 318.

McIntosh, H. W., and Holmes, C. B. (1951). Lancet, 2, 1061.

Oleesky, S., and Stanbury, S. W. (1951). Ibid., 2, 664.

Perera, G. A., and Ragan, C. (1950). Proc. Soc. exp. Biol., N.Y.,

Salassa, R. M. (1950). Proc. Mayo Clin., 25, 497.

Slessor, A. (1951). J. clin. Endocr., 11, 700.

Sprague, R. G., Power, M. H., and Masom, H. L. (1950). J. Amer. med. Ass., 144, 1341 .

Thorn, G. W., and Bayles, T. B. (1949). Practitioner, 163, 365.

- , Forsham, P. H., Frawley, T. F., Wilson, D. L., Renold, A. E., Fredrickson, D. S., and Jenkins, D. (1951). Amer. J. Med., 10, 595 .

Effets comparés de la cortisone, de l'ACTH, et du DOCA (acétate de desoxycorticostérone) dans un cas d'arthrite rhumatismale avec la maladie d'Addison

\section{RÉSUMÉ}

Les effets de l'ACTH, de la cortisone, et du DOCA, ainsi que ceux du DOCA associé à la cortisone, furent étudiés dans un cas d'arthrite rhumatismale compliqué d'insuffisance surrénale. On trouva que la cortisone seule contrôlait aussi bien les lésions articulaires que l'insuffisance surrénale. Il n'y eut pas, toutefois, de vraie inversion de la diurèse aqueuse après la cortisone. Les auteurs discutent la question de l'action de la cortisone par rapport à l'insuffisance rénale.

Efectos comparados de cortisona, ACTH, y de DOCA (acetato de desoxicorticosterona) en un caso de artritis reumatoide con la enfermedad de Addison

\section{Sumario}

Los efectos de la ACTH, de la cortisona, y del DOCA, así como los del DOCA y de la cortisona en combinación, fueron estudiados en un caso de artritis reumatoide complicado de insuficiencia suprarrenal. Se halló que la cortisona sola controlaba tanto las lesiones articulares como la insuficiencia suprarrenal. Verdadera inversión de la diuresis acuosa no tuvo lugar, sin embargo, después de la cortisona. Se discute la cuestíon de la acción de la cortisona en relación con la insuficiencia renal. 